\title{
The barbershop renovation: Prevention program for communicable diseases
}

\author{
Fikki Prasetya ${ }^{1}$, Pradhea Wulandari ${ }^{2}$ \\ ${ }^{1,2}$ Bagian Bagian Promosi Kesehatan Universitas Halu Oleo
}

\begin{abstract}
Infectious diseases such as HIV / AIDS and hepatitis are diseases that can be transmitted through various media, one of them through shaving tools that are not hygienic which is still rarely noticed by barber. Barbershop renovation is an educational program which was designed as an effort to prevent infectious diseases in Barbershop through education with the use of mirror stickers and shaving cloth media and assistance during the program. The purpose of this research is to determine the effectiveness of Barbershop's surgical program against the prevention of infectious diseases through a shaver at Barbershop in Kendari City in 2019. This study used quasiexperimental designs with a treatment-control group design (pre-test and post-test). A total of 30 Barbershops were involved in the study, which were selected by purposive sampling technique. Data analysis used Wilcoxon sign rank test for testing the difference between before and after treatment, and mann whitney U test, for testing the differences between the treatment and control groups. The results of data analysis showed differences in attitudes both before and after treatment. In addition we also found significant differences between the treatment group and the control group. So it could be concluded that the operation of the Barbershop renovation program was effective in providing education and influence the attitude about preventing transmission of infectious diseases through shavers. Suggestions that can be given are strengthening health strategies, like supervisory support and training is needed to facilitate effective preventive measures against infectious diseases among barbers Keywords: barbershop; shaver; communicable diseases; renovation
\end{abstract}

\begin{abstract}
ABSTRAK
Penyakit menular seperti HIV/AIDS dan hepatitis adalah penyakit yang dapat ditularkan melalui berbagai media, salah satunya melalui alat cukur yang tidak higienis yang masih jarang diperhatikan oleh pelaku Barbershop. Bedah Barbershop merupakan sebuah program edukasi yang didesain sebagai upaya pencegahan penyakit menular pada Barbershop, melalui edukasi dengan penggunaan media stiker cermin dan kain cukur, serta pendampingan selama program. Tujuan penelitan ini adalah untuk mengetahui efektivitas program bedah Barbershop terhadap pencegahan penyakit menular melalui alat cukur pada Barbershop di Kota Kendari tahun 2019. Penelitian ini menggunakan quasi-eksperimental designs, dengan rancangan kelompok perlakuan-kontrol (pre test dan post test). Sebanyak 30 Barbershop dilibatkan dalam penelitian, yang dipilih dengan teknik purposive sampling. Analisis data menggunakan wilcoxon sign rank test, untuk menguji perbedaan antara sebelum dan setelah perlakuan, serta mann whitney U test, untuk menguji perbedaan antara kelompok perlakuan dan kelompok kontrol. Hasil analisis data menunjukkan adanya perbedaan sikap baik sebelum maupun setelah perlakuan. Selain itu, kami juga menemukan perbedaan yang signifikan antara kelompok perlakuan dengan kelompok kontrol. Sehingga dapat disimpulkan bahwa bedah Program Bedah Berbershop efektif sebagai program untuk mengedukasi dan mempengaruhi sikap tukang cukur tentang pencegahan penularan penyakit menular melalui alat cukur. Saran yang dapat diberikan adalah penguatan strategi kesehatan, seperti dukungan pengawasan dan pelatihan diperlukan untuk memfasilitasi langkah-langkah pencegahan yang efektif terhadap penyakit menular di kalangan tukang cukur.
\end{abstract}

\section{PENDAHULUAN}

Virus hepatitis C (HCV) dan infeksi

HIV sering terjadi bersamaan karena rute

penularan bersama (Petersdorf et al., 2016).

Penyakit tersebut dapat menular melalui darah pada perlukaan yang terbuka (Vieira et al., 2017).

World Health Organisation (WHO), memprediksi bahwa pada tahun 2016 diseluruh dunia, terdapat 7134 kasus meninggal
Alamat Korespondensi:

Gedung FKM Universitas Halu Oleo Kendari

Email: fikki.prasetya@uho.ac.id
ISSN-P : 2086-2040

ISSN-E : 2548-5334

Volume 12, Nomor 1, Januari-Juni 2020 
disebabkan oleh Hepatitis (terhitung 0,5\% dari kematian karena virus hepatitis) (WHO, 2019).

Estimasi dan proyeksi jumlah orang dengan HIV/AIDS pada umur $\geq 15$ tahun di Indonesia pada tahun 2017 sebanyak 628.492 orang dengan jumlah infeksi baru sebanyak 46.357 orang dan kematian sebanyak 40.468 orang (Kemenkes RI, 2017).

Hasil Riset Kesehatan Dasar (Riskesdas) tahun 2013 memperlihatkan proporsi pengidap Hepatitis B sebesar 7,1\%, menurut jenis kelamin (laki-laki $8,0 \%$ dan perempuan $6,4 \%$ ), menurut lokasi tempat tinggal (perkotaan 6,3\% dan pedesaan 7,8\%). Menurut Data Dinas Kesehatan Provinsi Sulawesi Tenggara kota kendari tahun 2018 jumlah kasus penderita HIV/AIDS pada laki-laki sebanyak 15 orang dan perempuan sebesar 6 orang dengan jumlah 21 orang (Infodatin, 2017) .

Penularan virus HIV dan Hepatitis dapat menular melalui media alat cukur pada Barbershop, selama proses pemotongan rambut (Sultan, Yacoobmayet, Alaqeel, \& Al-Omar, 2018). Alat cukur yang biasanya menimbulkan perlukaan, dan berisiko menularkan penyakit ini adalah pisau cukur (Kamran, Ihsan, Ayaz, \& Ahmad, 2018).

Tempat tukang cukur adalah tempat di mana sering terdapat penggunaan pisau berulang, pemangkas dan gunting yang sama, bahkan seringkali tanpa sterilisasi atau desinfeksi yang tepat (Atmaja \& Ansari, 2018). Tukang cukur dan salon kecantikan yang melakukan praktik menusuk kulit, yang melibatkan instrumen atau peralatan tajam dan dapat digunakan kembali, dapat menghadirkan risiko penularan HIV dan patogen lainnya, yang ditularkan melalui darah (Abd, Al-qassab, \& Raman, 2020).

Sikap yang positif oleh tukang cukur tentang aktifitas potong rambut yang aman dari penularan penyakit perlu ditingkatkan, untuk mengurangi risiko penularan di tempat cukur rambut (Sultan et al., 2018). Dengan mengintervensi sikap, dapat berdampak pada praktik penggunaan alat cukur yang aman dari risiko penularan penyakit. Penekanan paling penting adalah pada saat antrian meningkat, sehingga menyebabkan tukang cukur lupa untuk mengganti silet cukurnya (Atmaja \& Ansari, 2018). Hasil penelitian Belbacha menunjukkan bahwa, seropositif HBV lebih rendah pada pangkas rambut yang menjaga kebersihan dan yang menggunakan antiseptik (Belbacha, Cherkaoui, Akrim, Dooley, \& El Aouad, 2011).

Hasil observasi yang pendahuluan dilakukan, ditemukan bahwa sebagian Barbershop melayani pelanggan dengan menggunakan silet cukur secara berulang dengan pelanggan yang berbeda-beda. Berbagai alasan yang diberikan, dari ketid- 
aktahuan mengenai dampak yang akan timbul, lupa ketika terburu-buru, maupun silet yang digunakan dianggap belum rusak dan lain sebagainya.

Upaya edukasi dibutuhkan dalam rangka meningkatkan kesadaran dalam upaya pencegahan penyakit menular melalui alat cukur, dengan merangsang peru- rancangan kelompok-kontrol (pre test dan post test). Sebanyak 30 Barbershop dilibatkan dalam program untuk penelitian yang merupakan Barbershop atau tempat cukur kecil, yang dipilih dengan teknik purposive sampling, dengan kriteria pemilihan Barbershop yang dijadikan sampel adalah memiliki tarif layanan dibawah Rp. 10.000,
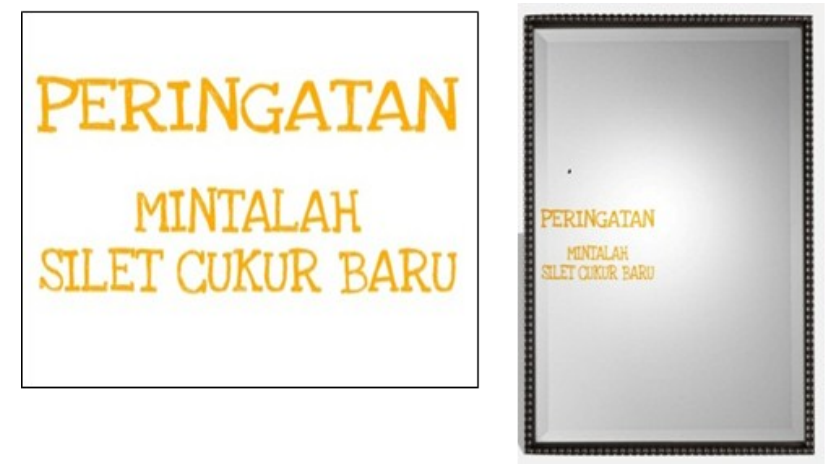
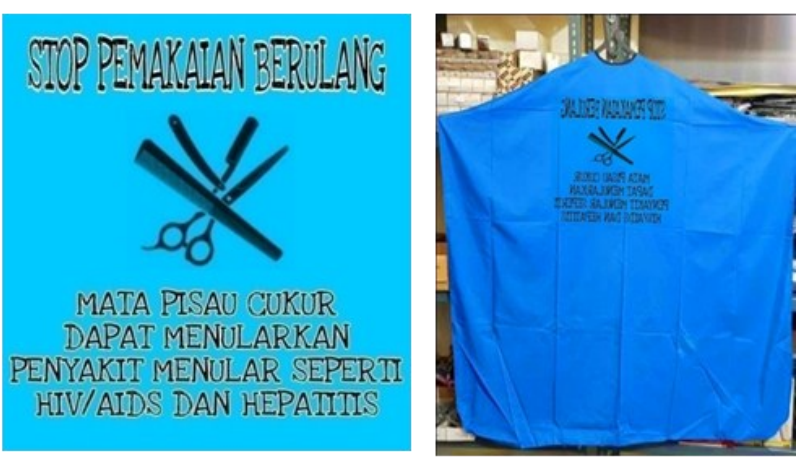

Gambar 1. Media yang digunakan pada program bedah barbershop: (a) Pesan pada stiker; (b) Penempatan stiker pada cermin; (c) Pesan pada kain cukur; (d) Penempatan pesan pada kain cukur.

bahan sikap pada tukang cukur di Barbershop (Atmaja \& Ansari, 2018; Joshan \& D’souza, 2015; Khairkhah et al., 2016), melalui rancangan intervensi program edukasi yang adekuat untuk mempengaruhi perilaku mereka (Joshan \& D'souza, 2015).

Penelitian ini bertujuan untuk menguji cobakan efektifitas progam bedah Barbershop, yang telah didesain sebelumnya, terhadap sikap tukang cukur pada Barbershop di Kota Kendari.

\section{METODE PENELITIAN}

Penelitian ini menggunakan metode Quasi-Experimental Designs, dengan
-. Hal ini dilakukan karena Barbershop yang bertarif murah, cenderung mengabaikan penggantian pisau/silet cukur dengan alasan profit. Sampel keseluruhan sejumlah 30 responden, dengan perbandingan sampel minimal 1:1, maka besar sampel untuk masing-masing kelompok intervensi dan kontrol adalah 15 responden.

Rancangan perlakuan yang diberi nama "Program Bedah Barbershop", dilakukan pada kelompok perlakuan/ eksperimen dan menggunakan kelompok kontrol. Sebanyak 15 responden yang terpilih sebagai kelompok perlakuan diberikan program bedah Barbershop. Pre test 
dilakukan dihari yang bersamaan dengan kelompok kontrol. Pada kelompok perlakuan, responden mendapatkan kain cukur, stiker, edukasi dan kunjungan selama 4 kali, untuk penguatan frekuensi edukasi pada program. Post test dilakukan pada saat program bedah Barbershop selesai dijalankan.

Sebanyak 15 responden yang terpilih sebagai kelompok kontrol, tidak diberikan program bedah Barbershop. Pre test dilakukan pada hari yang bersamaan dengan daan antara sebelum dan setelah perlakuan, serta mann whitney U test, untuk menguji perbedaan antara kelompok perlakuan dan kelompok kontrol.

\section{HASIL PENELITIAN}

Karakteristik responden berdasarkan usia pada tabel 1 , menunjukan bahwa pada kelompok perlakuan, usia 31 tahun - 40 tahun sebanyak 1 orang dengan presentase yang paling rendah yaitu sebesar $6.7 \%$. Se-

Tabel 1. Karakteristik Responden

\begin{tabular}{lcccc}
\hline \multirow{2}{*}{ Karakteristik } & \multicolumn{2}{c}{ Kelompok Perlakuan } & \multicolumn{2}{c}{ Kelompok Kontrol } \\
\cline { 2 - 5 } & $\mathrm{n}$ & $\%$ & $\mathrm{n}$ & $\%$ \\
\hline Usia & 4 & 26.7 & 6 & 40.0 \\
$11-20$ & 7 & 46.7 & 4 & 26.7 \\
$21-30$ & 1 & 6.7 & 3 & 20.0 \\
$31-40$ & 3 & 20.0 & 2 & 13.3 \\
$41-50$ & 15 & 100 & 15 & 100 \\
Jumlah & & & 15 & 100 \\
Jenis Kelamin & 15 & 100 & 0 & 0 \\
Laki-Laki & 0 & 0 & 15 & 100 \\
Perempuan & 15 & 100 & & \\
Jumlah & & & & \\
\hline
\end{tabular}

Sumber: Data Primer, 2019

kelompok perlakuan, dan dan post test pada hari yang sama dengan kelompok perlakuan. Pada gambar 1., menunjukkan media yang digunakan dalam program bedah Barbershop

Instrumen yang digunakan dalam pengumpulan dan pengolahan data ini yaitu menggunakan kuesioner, yang telah memenuhi memenuhi standar validitas dan reliabilitas. Analisis data menggunakan wilcoxon sign rank test, untuk menguji perbe- dangkan pada kelompok perlakuan di usia 21 tahun -30 tahun sebanyak 7 orang memiliki presentase yang paling tinggi yaitu sebesar $46.7 \%$.

Pada kelompok kontrol di usia 41 tahun - 50 tahun sebanyak 2 orang dengan presentase yang paling rendah yaitu sebesar $13.3 \%$. Sedangkan pada kelompok perlakuan di usia 11 tahun - 20 tahun sebanyak 6 orang memiliki presentase yang paling tinggi yaitu sebesar $40.0 \%$. Karakteristik re- 
sponden berdasarkan jenis kelamin pada tabel 1, menunjukkan baik kelompok perlakuan dan kontrol keseluruhan responden berjenis kelamin laki-laki (100\%).

Pada tabel 2, dapat dilihat distribusi hasil penilaian sikap berdasarkan pre-test dan post-test, pada masing-masing kelompok perlakuan dan kelompok kontrol. Berdasarkan tabel tersebut pada kelompok perlakuan menunjukkan bahwa, jawaban responden sebelum diberikan program be- dangkan nilai mean post-test sebesar 37,87 setelah diberikan intervensi dan nilai SD sebesar 1,84 .

Pada kelompok kontrol menunjukkan bahwa, jawaban responden pada pre-test tanpa diberikan perlakuan, nilai sikap paling tinggi adalah 34 sebanyak 1 responden (6.7\%) dan nilai sikap paling rendah adalah 18 sebanyak 1 responden (6.7\%). Sedangkan nilai sikap responden pada posttest tanpa perlakuan, paling tinggi adalah

Tabel 2. Distribusi Penilaian Sikap Responden pada Kelompok Perlakuan dan Kelompok Kontrol

\begin{tabular}{clcccc}
\hline & \multicolumn{1}{c}{ Statistik } & \multicolumn{2}{c}{ Kelompok Perlakuan } & \multicolumn{2}{c}{ Kelompok Kontrol } \\
\hline & & Pre-test & Post-test & Pre-test & Post-test \\
\hline 1 & Banyak Data & 15 & 15 & 15 & 15 \\
2 & Skor Terendah & 23 & 33 & 18 & 20 \\
3 & Skor Tertinggi & 36 & 40 & 34 & 34 \\
4 & Mean (Rata-Rata) & 30.53 & 37.87 & 29.67 & 29.2 \\
5 & SD & 2.90 & 1.84 & 3.65 & 3.29 \\
\hline
\end{tabular}

Sumber: Data Primer, 2019

dah Barbershop, nilai sikap sebesar 36 merupakan nilai paling tinggi yang diperoleh 1 responden $(6.7 \%)$, dan nilai sikap sebesar 23 merupakan skor paling rendah yang diperoleh 1 responden (6.7\%). Sedangkan nilai sikap responden setelah diberikan program bedah Barbershop yang paling tinggi adalah 40 sebanyak 5 responden $(33.3 \%)$ dan nilai paling rendah adalah 33 yang diperoleh 1 responden (6.7\%). Pada kelompok perlakuan nilai mean pre-test sebesar 30,53 dan SD atau sebaran data dalam sampel adalah 2,90 se-
34 sebanyak 1 responden (6.7\%) dan paling rendah adalah 20 sebanyak 1 responden (6.7\%). Pada kelompok kontrol nilai mean pre-test sebesar 29,67 dan SD atau sebaran data dalam sampel adalah 3,65 sedangkan nilai mean post-test sebesar 29,20 dan nilai SD sebesar 3,29.

Pada tabel 3, terlihat bahwa nilai negative ranks adalah 0 , baik pada nilai $\mathrm{N}$, mean rank, maupun sum rank. Disini terdapat 15 data positif $(\mathrm{N})$ dan Mean rank sebesar 8,00, sedangkan sum of ranks adalah sebesar 120,00. Ties sebesar 0. Ber- 
dasarkan output di atas, diketahui nilai signifikansi sebesar 0,001. Karena nilai 0,001 lebih kecil dari $(<)$ 0,05, maka dapat dikatakan terdapat perbedaan sikap Barbershop pada pre test ke post test.

Pada tabel 4, hasil uji Mann Whitney U, menunjukkan perbedaan nilai sikap melalui pemberian program bedah Barbershop pada kelompok perlakuan dengan mean rank atau rata-rata rangking adalah 23.00 dan nilai sum of ranks atau jumlah ranking adalah 345.00.

Sedangkan pada kelompok kontrol, nilai mean rank atau rata-rata rangking ada-

\section{PEMBAHASAN}

Dari hasil analisis data diketahui bahwa, nilai sikap dari kelompok perlakuan sebanyak 15 responden mengalami peningkatan hasil dari program bedah Barbershop dari nilai pre test ke post test. Allport mengatakan bahwa, pengetahuan, pikiran, keyakinan dan emosi meurpakan aspek dalam menentukan sikap yang utuh (Notoatmodjo, 2007).

Sikap yang baik akan membuat tukang cukur berupaya untuk melakukan pencegahan penyebaran penularan $\mathrm{HIV} /$ AIDS dan hepatitis melalui transmisi silet

Tabel 3. Hasil Wilcoxon Sign Ranks Test pada Kelompok Perlakuan

\begin{tabular}{lccc}
\multicolumn{1}{c}{ Sikap } & $\mathrm{n}$ & Mean Rank & Sum of Ranks \\
\hline post test- pre test & & 0.00 & 0.00 \\
Negative Ranks & $0^{\mathrm{a}}$ & 8.00 & 120.00 \\
Ties & $15^{\mathrm{b}}$ & & \\
Total & $0^{\mathrm{c}}$ & & \\
Sig. & 15 & & \\
\hline
\end{tabular}

Sumber: Data Primer, 2019

lah 8.00 dan nilai sum of ranks atau jumlah rangking adalah 120.00. Nilai mann whitney $\mathrm{u}$ adalah sebesar 0.000 dan nilai $\mathrm{Z}$ 4.690 dan $\mathrm{P}$ sebesar $0.000<0,05$, sehingga dapat dikatakan terdapat perbedaan sikap tentang pencegahan penyakit menular melalui alat cukur pada Barbershop, antara kelompok perlakuan dengan kelompok kontrol tanpa pemberian program bedah Barbershop. cukur (Khairkhah et al., 2016). Dalam berpikir, komponen emosi dan keyakinan ikut bekerja (Prasetya, 2020), sehingga tukang cukur berniat untuk menggunakan silet cukur yang steril atau yang baru kepada setiap pelanggan agar mengurangi risiko terjadinya penyebaran virus HIV/AIDS dan hepatitis, serta penyakit menular lainnya melalui transmisi alat cukur.

Dari hasil pengamatan dilapangan sebelum dilakukan intervensi, sebagian be- 
sar responden tidak setuju untuk menggunakan silet cukur baru. Hal ini dikarenakan salah satu alasan bahwa, mereka akan mengeluarkan biaya lebih banyak lagi ketika tukang cukur membeli banyak silet untuk penggantian pada setiap pelanggan. Akan tetapi, setelah mendapatkan intervensi dan kunjungan selama 4 kali, terlihat ada perubahan sikap, dimana tukang cukur mulai terpikir akan dampak negatif dari pemakaian silet cukur secara berulang.

Pengujian sikap kepada kelompok perlakuan berupa program bedah Barbershop, berupa kain cukur dan stiker, mem- shop untuk pre test dan post test, serta terdapat 15 tukang cukur mengalami peningkatan hasil dari program bedah Barbershop dari nilai pre test ke post test. Tidak terdapat Kesamaan nilai pre test dan post test, sehingga dapat dikatakan bahwa tidak ada nilai yang sama antara pre test dan post test. Berdasarkan analisa di atas, maka dapat disimpulkan bahwa terdapat perbedaan sikap antara hasil program bedah Barbershop untuk pre test ke post test.

Setelah dilakukan intervensi dan kunjungan sebanyak 4 kali, sebagian besar responden mengatakan akan mengganti silet

Tabel 4. Hasil Mann Whitney U Test antara Kelompok Perlakuan dan Kelompok Kontrol

\begin{tabular}{lccccc}
\hline & Mean Rank & Sum Of Ranks & $\begin{array}{c}\text { Mann- } \\
\text { Whitney U }\end{array}$ & Z & \\
\hline Kelompok Perlakuan & 23 & 345 & & & \\
Kelompok Kontrol & 8 & 120 & 0.00 & -4.690 & 0.000 \\
\hline
\end{tabular}

Sumber: Data Primer, 2019

iliki skor rata-rata lebih tinggi dibanding sikap responden sebelum diberikan program bedah Barbershop berupa kain cukur dan stiker. Pada tabel sikap, hasil negative ranks atau selisih (negatif) antara hasil pemberian program bedah Barbershop untuk pre test dan post test tidak ada, baik pada nilai $\mathrm{N}$, mean rank, maupun sum rank yang menunjukkan tidak adanya penurunan (pengurangan) dari nilai pre test ke post test. Positif ranks atau selisih (positif) antara hasil pemberian program bedah Barber- cukur atau menggunakan silet cukur baru jika ada pelanggan yang berbeda yang datang ke tempatnya.

Pada kelompok perlakuan, Media stiker yang ditempatkan pada cermin membuat pelanggan bertanya kepada tukang cukur, begitu pula dengan kain cukur yang telah dimodifikasi dengan menempelkan pesan untuk mengganti silet cukur yang baru agar terhindar dari penyakit menular, membuat tukang cukur dan pelanggan saling berinteraksi dan saling berbagi infor- 
masi. Tukang cukur juga dapat dimanfaatkan untuk berbagi informasi tentang penularan penyakit yang mungkin terjadi di Barbershop, pada waktu berinteraksi dengan pelanggannya (Wilson et al., 2019), sehingga dapat berperan sebagai mouth to mouth educator.

Materi yang dikembangkan dana digunakan dalam program ini, telah disesuaikan dengan kebutuhan dan selera responden yang terlibat, sehingga dengan materi tersebut membuat sikap tukang cukur menjadi positif. Terbukti pada pertanyaan yang terdapat dikuesioner, mengalami peningkatan setelah diberikan intervensi. Semua pertanyaan yang terdapat pada kuesioner mengalami peningkatan nilai sikap setelah dilakukan intervensi.

Menurut teori Health Belief Model (HBM), jika seseorang mempersepsikan kerentanan pribadi terhadap kondisi kesehatan yang serius (ancaman yang dirasakan), persepsi ini mengarah pada perubahan perilaku yang akan dipengaruhi oleh keyakinan orang tersebut mengenai manfaat yang dirasakan dari berbagai tindakan yang tersedia untuk mengurangi ancaman penyakit (Glanz, Rimer, \& Viswanath, 2008). Seperti ancaman pesan kesehatan yang telah ditempelkan di kain cukur, yaitu mata pisau/silet cukur dapat menularkan penyakit seperti HIV/AIDS dan hepatitis, pesan singkat tersebut yang akan membuat seseorang untuk bertindak mengambil keputusan agar tidak terkena penyakit tersebut.

Bertambahnya informasi dapat merubah sikap seseorang (Notoatmodjo, 2007; Prasetya, 2020). Dalam hal ini, pengetahuan yang diperoleh tukang cukur selama diadakannya penelitian ini, sedikit demi sedikit mempengaruhi sikap dan tindakannya dalam mencegah penularan penyakit melalui alat cukur di Barbershop.

Berbeda halnya dengan kelompok kontrol yang mengalami peningkatan dan penurunan tanpa adanya intervensi dilakukan. Peningkatan dan penurunan pada saat post-test terjadi akibat pada kelompok kontrol tidak diberikan intervensi, sehingga responden pada kelompok kontrol tidak mendapatkan edukasi dan kunjungan. Adapun hal-hal yang dapat menyebabkan bias pada kelompok perlakuan dan kelompok kontrol adalah, responden dapat memperoleh informasi yang sama yang digunakan pada program langsung dari handphone mereka, ataupu informasi yang didapatkan dari orang lain baik itu dari keluarga,teman bahkan pelanggan yang datang ke tempat tukang cukur.

Kecenderungan untuk bertindak, memerlukan fasilitas dan faktor dukungan dari pihak lain. Perlunya motivasi dan dukungan dari pihak-pihak yang terkait dengan kesehatan masyarakat, agar semakin 
meningkatkan strategi edukasi untuk mempengaruhi sikap yang berujung pada praktik mencukur yang aman dari trasnmisi penyakit menular oleh tukang cukur di Barbershop (Atmaja \& Ansari, 2018).

\section{KESIMPULAN}

Dari hasil analisis data diketahui bahwa ada perbedaan sikap tukang cukur pada kelompok perlakuan sebelum dan sesudah diberikan program bedah Barbershop sehingga dapat dikatakan bahwa program bedah Barbershop mampu meningkatkan sikap tukang cukur dalam mencegah penularan penyakit menular melalui alat cukur pada Barbershop di Kota Kendari. Hal tersebut diperkuat dengan adanya perbedaan hasil pengukuran pada kelompok perlakuan dengan kelompok kontrol, sehingga dapat ditarik kesimpulan bahwa program bedah berbershop efektif dalam mencegah penularan penyakit menular melalui alat cukur.

\section{SARAN}

Bagi Dinas Kesehatan Kota Kendari dapat memanfaatkan program serupa dalam melakukan pencegahan dini terkait penyakit menular pada Barbershop, dapat didukung dengan mengeluarkan kebijakan tentang kewajiban menggunakan himbauan penggantian alat cukur yang aman. Strategi kesehatan seperti dukungan pengawasan dan pelatihan diperlukan untuk memfasili- tasi langkah-langkah pencegahan yang efektif terhadap penyakit HIV di kalangan pekerja salon kecantikan dan tukang cukur. Bagi peneliti selanjutnya dapat melakukan penelitian serupa, dengan menambahkan item edukasi lainnya tentang pencegahan penyakit menular di Barbershop.

\section{DAFTAR PUSTAKA}

Abd, R. K., Al-qassab, T., \& Raman, V. (2020). HIV / AIDS Awareness of People Who Work at Barbershops and Beauty Salons at AlNasiriya City in Iraq. 11(03), 1041-1047.

Atmaja, B. P., \& Ansari, E. R. (2018). Hubungan antara Pengetahuan dan Sikap Tukang Cukur Tentang HIV/AIDS dengan Perilaku Pencegahan Penularan HIV/AIDS melalui Transmisi Pisau Cukur. Jurnal Darul Azhar, 4(1), 52-61. https:// doi.org/10.1017/ CBO9781107415324.004

Belbacha, I., Cherkaoui, I., Akrim, M., Dooley, K. E., \& El Aouad, R. (2011). Seroprevalence of hepatitis $\mathrm{B}$ and $\mathrm{C}$ among barbers and their clients in the Rabat region of Morocco. Eastern Mediterranean Health Journal, 17(11), 911-919. https:// doi.org/10.26719/2011.17.12.91 1

Glanz, K., Rimer, B. K., \& Viswanath, K. (2008). Health Behavior and Health Education: Theory, Research and Practice. San Francisco: Jossey Bass.

Infodatin. (2017). SITUASI PENYAKIT 
HEPATITIS B di INDONESIA TAHUN 2017. In Journal of Chemical Information and Modeling (Vol. 53). Jakarta, Indonesia.

Joshan, P. ., \& D'souza, J. (2015). Effectiveness of Planned Teaching Programme on Knowledge and Practice regarding occupational risk of Blood Borne Disease among Barbers in selected Urban areas of Mangalore. Asian Journal of Nursing Education and Research, 5(3), $392 . \quad$ https:// doi.org/10.5958/2349-

2996.2015.00079.8

Kamran, S. M., Ihsan, H. R., Ayaz, S. Bin, \& Ahmad, M. (2018). Frequency, Risk Factors, and Genotypes for Hepatitis C Virus in Healthy Male Individuals from Okara Garrison. Pak Armed Forces Med Cal Journal, 68(6), 11-13.

Kemenkes RI. (2017). Profil Kesehatan Republik Indonesia Tahun (2017). Jakarta, Indonesia.

Khairkhah, T., Shamsa, A., Roohi, A., Khoshnoodi, J., Rajabpour, V. F., Tabrizi, M., ... Shokri, F. (2016). Analysis of knowledge, attitudes, and prevalence of hepatitis $\mathrm{B}$ and $\mathrm{C}$ seromarkers among barbers in Tehran. Hepatitis Monthly, 16(9). https://doi.org/10.5812/ hepatmon.39416

Notoatmodjo, S. (2007). Promosi Kesehatan dan Ilmu Perilaku. Jakarta: Rineka Cipta. Jakarta: PT. Rhineka Cipta.

Petersdorf, N., Ross, J. M., Weiss, H. A., Barnabas, R. V., Wasserheit, J. N., Beguelin, C., ... Sullivan, P. (2016). Systematic review and meta-analysis of hepatitis $\mathrm{C}$ virus infection and HIV viral load: New insights into epidemiologic synergy. Journal of the International AIDS Society, 19 (1). https://doi.org/10.7448/ IAS.19.1.20944

Prasetya, F. (2020). Buku Ajar Psikologi Kesehatan. Bogor: Kreatif Publishing.

Sultan, N. Y., Yacoobmayet, A., Alaqeel, S. A., \& Al-Omar, H. A. (2018). Assessing the level of knowledge and available sources of information about hepatitis $\mathrm{C}$ infection among $\mathrm{HCV}$-infected Egyptians. BMC Public Health, 18(1), 1-9. https:// doi.org/10.1186/s12889-0185672-6

Vieira, P. C. M., Lamarão, L. M., Amaral, C. E. de M., Corrêa, A. S. de M., de Lima, M. S. M., Barile, K. A. dos S., ... Burbano, R. M. R. (2017). Residual risk of transmission of human immunodeficiency virus and hepatitis $\mathrm{C}$ virus infections by blood transfusion in northern Brazil. Transfusion, 57(8), 19681976. https://doi.org/10.1111/ trf. 14146

WHO. (2019). Global Hepatitis Report 2019. Geneva, Swiss.

Wilson, T. E., Gousse, Y., Joseph, M. A., Browne, R. C., Camilien, B., McFarlane, D., ... Fraser, M. (2019). HIV prevention for black heterosexual men: The Barbershop talk with brothers cluster randomized trial. American Journal of Public Health, 109(8), 1131-1137. https://doi.org/10.2105/ AJPH.2019.305121 